\title{
Causation in Toxic Torts: Burdens of Proof, Standards of Persuasion, and Statistical Evidence
}

\author{
Steve Gold
}

Toxic torts ${ }^{1}$ present major challenges to tort law and the judicial system. ${ }^{2}$ Causation requirements pose one such challenge. Proving the cause of injuries that remain latent for years, are associated with diverse risk factors, and occur at background levels even without any apparent cause, ${ }^{3}$

1. Adhering to the tradition that a footnote appear within the first clause of any Note, I here attempt to define "toxic tort." A functional description, stating characteristics common to most such cases, suffices for the purposes of this Note. Typically, a toxic tort case involves an alleged personal injury and related harm resulting from exposure to a toxic substance-usually a chemical, but perhaps a biological or radiological agent. Generally, in toxic torts: (1) the injury is neither traumatic nor an acute toxic response, but results from genetic or biochemical disruption; (2) exposure is typically, though not necessarily, chronic and repeated; (3) injury manifests itself after a latency period.

Well-known toxic tort cases, in this sense, include: vaginal clear cell adenomas allegedly caused by maternal exposure to diethylstilbestrol (DES); asbestos workers' claims for various lung diseases; Vietnam veterans' claims that they were injured by exposure to dioxin-contaminated Agent Orange. Increasingly, claims based on exposure to hazardous wastes are being reported. See, e.g., Pereira v. Dow Chem. Co., 129 Cal. App. 3d 865, 181 Cal. Rptr. 364 (1982) (employe exposed to epoxies and organic solvents suffered kidney failure); Johnson v. Tipton, 103 Ill. App. 3d 291, 431 N.E.2d 464 (1982) (farm's well polluted by metals and phenols from neighbor's dump). Cases stemming from the swine flu vaccine program are an unusual but significant example. See infra notes 55,64 .

2. Various problems unique to toxic torts, not discussed in this Note, have been considered elsewhere. See, e.g., Estep \& Van Dyke, Radiation Injuries: Statute of Limitations Inadequacies in Tort Cases, 62 Mich. L. REv. 753 (1964) (latency causing bar of claims by laches); Locks, AsbestosRelated Disease Litigation: Can the Beast Be Tamed?, 28 VILL. L. Rev. 1184, 1189-93 (1982-1983) (high cost of toxic tort suits); Note, Class Certifications in Mass Accident Cases Under Rule 23(b)(I), 96 HARv. L. REv. 1142 (1983) (class treatment desirable but problematic).

Some commentators find these problems so compelling, they advocate replacing the tort system with an administrative compensation scheme. See, e.g., Ginsberg \& Weiss, Common Law Liability for Toxic Torts: A Phantom Remedy, 9 HofsTRA L. REv. 859 (1981); Trauberman, Statutory Reform of "Toxic Torts": Relieving Legal, Scientific, and Economic Burdens on the Chemical Victim, 7 HARv. ENvrL. L. REv. 177 (1983). Since no comprehensive administrative solution has been implemented, this Note assumes that the tort system will remain a major source of compensation for toxic tort victims. Even if administrative compensation were adopted, the program, like worker's compensation agencies, would face many of the same causation problems that confront tort plaintiffs. See, e.g., Hebert v. Lake Charles Am. Press, 427 So. $2 d 916$ (La. Ct. App. 1983) (respiratory ailment presumed to be result of occupational exposure to toxic chemicals); Olson v. Federal Am. Partners, 567 P.2d 710 (Wyo. 1977) (statistically proven increased risk did not prove uranium miner's cancer was work-related). Moreover, unless the compensation agency's jurisdiction were very vaguely defined, newly emergent toxic tort cases would likely follow the course of the asbestos litigation: that is, begin in the courts and finally, once liability were fairly clear, possibly be referred to the agency. See $P$. Brodeur, Outrageous Misconduct 310-15 (1985) (plaintiff' verdicts provide impetus to administrative proposals).

3. See generally Black \& Lilienfeld, Epidemiologic Proof in Toxic Tort Litigation, 52 FordHaM L. REv. 732, 744-49 (1984) (case examples); McElveen \& Eddy, Cancer and Toxic Substances: The 
is the "central problem"4 for toxic tort plaintiffs. Many commentators have proposed major doctrinal changes to ease this problem. ${ }^{5}$ Although courts have not adopted these proposals, ${ }^{6}$ they have allowed litigants to place increasing reliance on epidemiological or statistical proof in answering cause-in-fact questions. ${ }^{7}$

Problem of Causation and the Use of Epidemiology, 33 CLev. ST. L. REv. 29, 31-37 (1984-1985) (general discussion).

4. Trauberman, Compensating Victims of Toxic Substances Pollution: An Analysis of Existing Federal Statutes, 5 HARv. ENVTL. L. REv. 1, 3 (1981).

5. E.g., Delgado, Beyond Sindell: Relaxation of Cause-in-Fact Rules for Indeterminate Plaintiffs, 70 CALIF. L. REv. 881 (1982) (favors shifting burden to defendants and making recovery proportional to probability of causation); Lansing, The Motherless Calf, Aborted Cow Theory of Cause, 15 ENVTL. L. 1 (1984) (advocates abandonment of causation requirement in favor of "consistency" rule); Note, Tort Actions for Cancer: Deterrence, Compensation, and Environmental Carcinogenesis, 90 YALE L.J. 840 (1981) (advocates burden shifting); Note, Trans-Science in Torts, 96 YALE L.J. 428 (1986) [hereinafter Trans-Science] ("qualitative" causation standard, with burden shifting and negligence requirement); see also Comment, Judicial Attitudes Towards Legal and Scientific Proof of Cancer Causation, 3 Colum. J. ENvTL. L. 344 (1977) (proposes adopting medical model of multiple causation); Note, Establishing Causation in Chemical Exposure Cases: The Precursor Symptoms Theory, 35 RUTGERS L. REv. 163 (1982) (advocates relaxing causation requirement where medically consistent "precursors" manifest).

6. The changes advocated by the scholars listed supra note 5 and infra note 18 have not been adopted by courts. These are to be distinguished from other novel theories that relate to causation but involve apportionment of liability among defendants. The most notable of these is the "market share" approach used in some DES cases. E.g., Sindell v. Abbott Laboratories, 26 Cal. 3d 588, 607 P.2d 924, 163 Cal. Rptr. 132, cert. denied, 449 U.S. 912 (1980). In Sindell, though the link between DES and plaintiff's illness was well-established, proving which of several manufacturers had produced the particular injury-causing pills was problematic. This Note deals with cases in which, whether or not the relevant defendant is precisely identified, causation is in doubt for other reasons: either poor documentation of the substance-disease link, or links between the disease and other environmental causes or idiopathic origins. At least superficially, this "indeterminate plaintiff" problem is different from the "indeterminate defendant" of Sindell-type cases. See Delgado, supra note 5. Analytically, however, the two kinds of causal indeterminacy pose a single issue: how should tort law respond to cases in which a range of plausible alternate causes cannot conclusively be ruled out, and causation must be expressed probabilistically? The only distinction is whether the plausible alternate cause is produced by a named defendant or not. In many situations, both kinds of indeterminacy will coexist. "Toxic soups" in hazardous waste dumps are exemplary. Suppose a suit against Defendant Chemical Company alleges that the company's PCBs in the dump caused plaintiffs cancer. Defendant could interpose as alternate causes: non-defendant companies' PCBs; other chemicals in the dump, such as heavy metals; or background risk, rather than anything in the dump at all. Generally, there is no justification for treating alternate causes in different ways simply because they are or are not produced by named defendants. See generally Fraser \& Howarth, More Concern for Cause, 4 LEGaL, STud. 131, 137-38 (1984) (in valuation of injuries, defendant or non-defendant status of accused cause should not matter).

7. See, e.g., Ellis v. International Playtex, Inc., 745 F.2d 292 (4th Cir. 1984) (tampons/toxic shock syndrome); Needham v. White Laboratories, 639 F.2d 394 (7th Cir. 1981) (DES/adenoma), cert. denied, 454 U.S. 927 (1981); In re "Agent Orange" Prod. Liab. Litig., 611 F. Supp. 1223 (E.D.N.Y. 1985) [hereinafter Agent Orange Opt Out Opinion] (Agent Orange/numerous diseases; dismissing suits of plaintiffs who opted out of class action) ; Johnston v. United States, 597 F. Supp. 374 (D. Kan. 1984) (radiation from luminous dials/various cancers); Allen v. United States, 588 F. Supp. 247 (C.D. Utah 1984) (radiation/leukemia); Brafford v. Susquehanna Corp., 586 F. Supp. 14 (D. Colo. 1984) (uranium tailings/cancer risk); Kehm v. Procter \& Gamble, 580 F. Supp. 890 (N.D. Iowa 1982) (tampons/toxic shock syndrome); Cook v. United States, 545 F. Supp. 306 (N.D. Cal. 1982) (swine flu vaccine/Guillain-Barré Syndrome); In re Swine Flu Immunization Prods. Liab. Litig., 495 F. Supp. 1188 (D. Colo. 1980) (same). But see Szczepaniak v. United States, No. 80-990MA (D. Mass. Mar. 2, 1985) (swine flu; epidemiology not probative of causation); Sulesky v. United States, 545 F. Supp. 426, 430 (S.D. W. Va. 1982) (swine flu; epidemiology "not determinative" to 
This Note examines the doctrinal issues raised by the growing primacy of statistical proof in toxic tort litigation. ${ }^{8}$ Part I demonstrates that the use of statistical proof of causation has created confusion between the substantive burden of proof and the standard of persuasion which must be met to satisfy the burden. Formerly the "fact" of causation (burden) had to be supported by a "preponderance of the evidence" (standard). "Preponderance" was defined probabilistically: the jury had to be persuaded that the fact was "more likely than not" true. But in toxic torts, the statistical causation evidence is also expressed probabilistically-as a factual estimate of the defendant's contribution to the plaintiff's risk. The failure to distinguish between the two kinds of probability has led to the collapse of the factual burden and preponderance standard into a single test: does the factual probability of causation exceed 50\%? The result, explained in Part II, is that the standard of persuasion loses its meaning. Furthermore, this "collapsing" works hidden doctrinal changes and encourages the application of simple-minded quantitative rules and narrow limits on evidence. Part III proposes an approach which minimizes these consequences and, compared to either the status quo or other reform proposals, better meets diverse and sometimes conflicting tort law goals. It suggests adapting to the problems of toxic tort causation by (1) considering a broad range of evidence; (2) distinguishing clearly between burdens of proof (statistical

"establish" causation or lack thereof); see also Wells v. Ortho Pharmaceutical Corp., 788 F.2d 741 (11th Cir. 1986) (spermicide/birth defects; causation could be proven to "reasonable medical certainty" by expert testimony though epidemiological studies did not clearly support causation), cert. denied, 55 U.S.L.W. 3333 (U.S. Nov. 11, 1986); Gassman v. United States, 589 F. Supp. 1534, 1542 (M.D. Fla. 1984) (absence of statistical epidemiological evidence "strongly disfavors," but does not rule out, causation; verdict for plaintiff in swine flu case absent evidence of alternate causes), affd, 768 F.2d 1263 (11th Cir. 1985).

8. The propriety of admitting epidemiological evidence is debated. For arguments in favor of using epidemiology, see Black \& Lilienfeld, supra note 3, at 762-64 (epidemiological indicia of reliability are appropriate for evidentiary standard); Hall \& Silbergeld, Reappraising Epidemiology: $A$ Response to Mr. Dore, 7 Harv. EnvTl. L. REv. 441 (1983) (epidemiological studies are most appropriate causation evidence in toxic torts); McElveen \& Eddy, supra note 3, at 66-67 (advocates relatively restricted use of epidemiology); Comment, Epidemiologic Proof of Probability: Implementing the Proportional Recovery Approach in Toxic Exposure Torts, 89 DICK. L. Rev. 233 (1984) (favors exclusive use of epidemiology). But see Dore, A Commentary on the Use of Epidemiological Evidence in Demonstrating Cause-in-Fact, 7 Harv. ENvTL. L. REv. 429 (1983) (epidemiological evidence inappropriate as proof of causation in individual cases). If courts do hear epidemiological evidence, they should know how to evaluate its quality scientifically. See Large \& Michie, Proving that the Strength of the British Nayy Depends on the Number of Old Maids in England: A Comparison of Scientific Proof with Legal Proof, 11 ENvTL. L. 555 (1981) (primer on making such evaluations).

This Note assumes that scientifically sound epidemiological and statistical evidence will play a role in toxic tort causation controversies. See infra notes 11-18 and accompanying text. It argues for doctrinal changes which can define that legal role in a manner that is consistent with scientific reality and the limitations inherent in even the best-designed scientific study.

Increased acceptance of epidemiological proof may be viewed as a pro-plaintiff development, since it tends to relieve plaintiffs of the nearly impossible task of providing "particularistic" proof. But both plaintiffs and defendants have successfully used epidemiological evidence. See Hall \& Silbergeld, supra, at 446-47; see also Agent Orange Opt Out Opinion, 611 F. Supp. at 1231-34 (epidemiological studies tend to show no causal connection between Agent Orange exposure and health effects). 
probability as the fact being proven) and standards of persuasion (probabilities of belief); (3) replacing the $>50 \%$ rule with a substantial factor test; and (4) allowing discounted recoveries to reflect uncertainty. ${ }^{\circ}$

\section{Statistics and Changing Burdens of Proof}

The increasing use of statistical evidence as proof of toxic tort causation is largely a result of simple necessity. ${ }^{10}$ Because statistical associations of disease with toxic substances can be expressed as probabilities, courts seemingly have had little trouble applying a probabilistic standard of persuasion to this type of evidence. However, this application confounds two distinct types of "probability," creating confusion in legal doctrine.

\section{A. Need for Statistical Evidence}

The basic impossibility of proving individual causation distinguishes toxic tort cases from ordinary personal injury suits. Gancers and mutations provide no physical evidence of the inducing agent, ${ }^{11}$ so direct observation of individual plaintiffs provides little or no evidence of causation in many instances. Often, parties must rely on epidemiological evidence, which may become the centerpiece of toxic tort litigation. ${ }^{\mathbf{2}}$

The hallmark of epidemiology is that it is based on the study of popula-

9. In some cases where no liability would be found under traditional tort rules, this proposal might allow for partial recovery. However, it is less generous to plaintiffs than some other reform proposals. The goal is to favor neither plaintiffs nor defendants but to establish causation rules which relate rationally to scientific reality.

10. Even critics of this trend acknowledge that it is likely to continue. Dore, A Proposed Standard for Evaluating the Use of Epidemiological Evidence in Toxic Tort and Other Personal Injury Cases, 28 How. L.J. 677, 693 (1985) (arguing that epidemiology should not be used, but conceding "[i]n light of the difficulty in developing direct proof in [toxic tort and similar cases], many courts have simply refused to accept this result.") (footnote omitted).

Consistent with his view that "it would indeed be rare if not unheard of for . . . a particular epidemiological study to truly advance the judicial resolution of a causation question applicable to any particular individual claimant," id. at 691, Dore proposes an evidentiary standard so stringent that it would essentially exclude such studies. One element of the standard would be an unusually strict test of statistical significance. See infra note 74.

11. S. EPSTrin, The Polrtics of CANCER 40 (1978); Estep, Radiation Injuries and Statistics: The Need for a New Approach to Injury Litigation, 59 Mich. L. Rev. 259, 266-67 (1960); Rudlin, Burdens of Proof, in Toxic TorTs 464 (G. Nothstein ed. 1984); see also Weinstein, Preliminary Reflections on the Law's Reaction to Disasters, 11 Colum. J. EnvTL. L. 1, 10 n.24 (1986) (specific causal chains not identifiable in toxic torts).

12. Trans-Science, supra note 5 , at $429 \mathrm{n} .11$, suggests that truly trans-scientific cases are beyond the scope of this Note's concern with the use of existing epidemiological evidence. This dichotomy makes sense in principle. In practice, however, it would be difficult or impossible to operate two causation regimes, one for trans-scientific and one for scientific toxic torts. This Note's approach, particularly with respect to the "substantial factor" test, see infra text accompanying notes 96-104, and the types of admissible evidence, see infra text accompanying notes 89-95, could encompass most trans-scientific cases. At the same time, this Note challenges the Trans-Science suggestion that a proper epidemiological study, if possible, could provide a scientific answer that would be legally conclusive. See infra text accompanying notes 79-83, 89-95. 
tions ${ }^{13}$ not individuals. ${ }^{14}$ It seeks to establish associations between alleged causes and effects by one of two methods: either comparing the incidence of disease across exposed and unexposed populations, or comparing the incidence of exposure across sick and healthy populations. ${ }^{15}$ With proper scientific interpretation, these correlations lend great weight to an inference of causation. ${ }^{16}$ However, in an individual case, epidemiology cannot conclusively prove causation; at best, it can establish only a certain probability that a randomly selected case of disease was one that would not have occurred absent exposure, or the "relative risk" of the exposed population. ${ }^{17}$ Toxic tort litigation, therefore, involves inferences on causation derived from group-based information, ${ }^{18}$ rather than specific conclusions regarding causation in the individual case. ${ }^{19}$

\section{B. Preponderance Standard and Burden of Proof Collapsed into One}

To understand the effect of substituting population-based inferences for specific, individualized conclusions, it is necessary to distinguish clearly between burdens of proof and standards of persuasion. As used here, "burden of proof"20 refers to those facts which a plaintiff" must prove to

13. In statistics, the technical meaning of "population" is the universe from which a sample is drawn. Unless the context clearly implies the technical meaning, in this Note "population" simply means "group" as opposed to individual.

14. J. Mausner \& A. Bahn, Epidemiology 4 (1974) ("epidemiology is concerned with . . . illnesses and injuries in groups of people"); Black \& Lilienfeld, supra note 3, at 755; see Muir \& Higginson, Role of Epidemiology in Identifying Chemical Carcinogens, in Handbook of CarcinoGen Testing 28 (H. Milman \& E. Weisburger eds. 1985). The cases cited at the end of note 7, supra, make use of this fact to ignore or give less credit to epidemiological evidence of causation.

15. This simplification captures the essence of epidemiological research on disease causation. A. LiLIENFELD, Foundations of EPIDEMIOLOGY 14 (1976). These comparisons, commonly called cohort studies and case-control studies, respectively, embrace a variety of subtly different experimental designs requiring different modes of analysis. See id. at 164-229.

16. See Black \& Lilienfeld, supra note 3, at 762-64.

17. Black \& Lilienfeld, supra note 3, at 755-61; Dore, supra note 8, at 431-33. "Relative risk" is simply the ratio of the incidence of disease in the exposed population to the incidence of disease in the non-exposed population.

18. A number of commentators have suggested schemes explicitly incorporating such estimates of probabilities into causation findings. The most thorough is Rosenberg, The Causal Connection in Mass Exposure Cases: A "Public Law" Vision of the Tort System, 97 HARv. L. Rev. 851 (1984) (arguing for "proportional recovery": total damages multiplied by established probability of causation); see also Delgado, supra note 5, at 899-902; Page, On the Meaning of the Preponderance Test in Judicial Regulation of Chemical Hazards, 46 LAw \& ConTEMP. Probs. 267 (1983) (would allow recovery if probability of causation exceeded critical value determined by cost-benefit analysis in each case); Note, A Suggested Remedy for Toxic Injury: Class Actions, Epidemiology, and Economic Efficiency, 26 WM. \& MARY L. REv. 497 (1985) (proportional recovery similar to Rosenberg).

19. Statistical evidence may nonetheless be used, like any other evidence, to support inferences about causation. Suppose, for example, that we wanted to prove that at a certain time a calculator's read-out displayed " 4 ." If we had a videotape of a person at that time pushing the keys " $2+2=$ ", and statistical evidence that random calculator errors in addition were a one-in-a-billion event, we would confidently conclude that the screen read " 4 ." But that is still quite different from looking at the screen and seeing what it reads.

20. Because "burden of proof" includes a number of related concepts, unambiguous use of the 
establish a prima facie case. ${ }^{22}$ In a products liability case, for example, a plaintiff must establish the existence of a product defect, harm suffered, and a causal link between defect and harm. On each element of the prima facie case, and each affirmative defense, the jury reaches a finding of fact: either there was a defect or there wasn't, etc. The conclusion on each element is unequivocal-the jury decides which version of the facts it believes. ${ }^{23}$ Of course, no one ever knows the truth for sure, and the jury's belief need not be absolute. The standard of persuasion, as that term is used here, defines the level of confidence that the jury must feel in order to find a fact "true" in favor of the party with the burden of proving that fact. ${ }^{24}$ A standard of persuasion represents a degree of certainty in the jury's collective mind, which can be characterized as a "probability."25 Thus, in a conventional case, only the issue of the sufficiency of the jury's belief in certain facts, measured against the standard of persuasion, involves probability. The facts themselves, defined as elements on which one party has the burden of proof, are deemed true or false, with no room for intermediate probabilities. ${ }^{28}$

term is difficult. Consider this example: "One area in which a comparison of legal rules with probability theory may be helpful is that of the burden of proof, or measure of persuasion." Ball, The Moment of Truth: Probability Theory and Standards of Proof, 14 VAND. L. REv. 807, 807 (1961). It may simplify matters for the reader to think in terms of the causation "element," on which plaintiff has the burden of proof. See King, Causation, Valuation, and Chance in Personal Injury Torts Involving Preexisting Conditions and Future Consequences, 90 YALE L.J. 1353, 1355 (1981).

21. The discussion focuses on plaintiffs because they must prove cause-in-fact; however, the analysis also applies to affirmative defenses.

22. See Mc.Cormick on Evidence $\S 337$ (E. Cleary 3d ed. 1984) [hereinafter McCormick].

23. Some courts have explicitly held that, notwithstanding the doubt permitted by the preponderance standard, the jury must have "actual belief in [the] truth" of each element of the case. Sargent v. Massachusetts Accident Co., 307 Mass. 246, 250, 29 N.E.2d 825, 827 (1940); Northern Va. Power Co. v. Bailey, 194 Va. 464, 471, 73 S.E.2d 425, 429 (1952); see also Arena Co. v. Minneapolis Gas Co., 234 F.2d 451, 458 (8th Cir. 1956) ("the burden is on the plaintiffs to persuade the trial court that their theory as to the cause of the fire is correct ....."). Another way of putting this is to say that jurors must "determine 'what really happened." Holstein, Jurors' Interpretations and Jury Decision Making, 9 LAw \& Hum. BeHav. 83, 83 (1985). Cf. In re Winship, 397 U.S. 358, 370 (1970) (Harlan, J., concurring) ("intensity of [jury's] belief . . . that a given act actually occurred" measured against preponderance standard).

24. See McCormick, supra note $22, \S 339$.

25. The three commonly used standards of persuasion are "beyond a reasonable doubt" (criminal cases), "by clear and convincing evidence" (some civil cases), and "by a preponderance of the evidence" (most civil cases, including toxic torts). See id. Attempts have been made to quantify the belief probabilities these verbal standards represent, and to study the effect of expressing standards numerically. See, e.g., Kagehiro \& Stanton, Legal vs. Quantified Definitions of Standards of Proof, 9 Law \& Hum. Behav. 159 (1985). See generally I. Hacking, The Emergence of Probability 73 (1975) (degree of belief understandable without quantitative analysis but concept did not in fact develop until numerical methods were applied).

26. Compare McCormick, supra note 22, § 339 with Prosser and KeEton on THE LAW OF ToRTs $\S 41$ (W. Keeton 5th ed. 1984) [hereinafter Prosser \& KeETON]. These hornbooks evince the traditional distinction between "burden" and "standard." PROSSER \& KeEToN's discussion of the cause-in-fact burden repeatedly treats the fact to be proven as a true-or-false proposition. By contrast, MCCormick properly identifies the preponderance standard as "concerned with the state of the jury's mind." (Prosser \& KeETon, supra, § 41, at 269, discusses probabilities, but only regarding 
Suppose, however, that the issue in a case involved an allegedly unfair coin that had been tossed to start a football game. Then, a question of fact would itself be about a "probability"-whether the coin, when flipped, really gave a fifty-fifty chance of heads or tails. In toxic torts, the nature of statistical proof similarly introduces probability into the arena of fact. ${ }^{27}$

\section{Fact Probability and Belief Probability}

The dual nature of probability, as both a measure of strength of belief and a factual statistical quantity, has existed for as long as the concept of probability itself. ${ }^{28}$ This duality has spawned considerable debate among mathematicians and philosophers, ${ }^{20}$ as well as among law professors, ${ }^{30}$ about the true nature of probability and its role in the courtroom. This Note does not debate whether probability is "subjectivist" ("degree of rational belief . . . represented, for example, by the willingness to make a bet at some odds") 31 , or "frequentist" ("relative frequency of a particular event in a sequence of experiments"), ${ }^{32}$ or something else; ${ }^{33}$ rather, it analyzes the doctrinal consequences of probability's dual nature. ${ }^{34}$ Standards of persuasion are most appropriately thought about as probability in the subjectivist sense. However, the availability, in toxic torts, of "frequentist" probability values derived from epidemiological studies, combined with failure to recognize the distinction, has caused widespread confusion.

An example illustrates the distinction between the two types of probability. A traffic light fails to turn red and a crash ensues. The city, sued for its defective light, argues that the car could not have stopped in time even had the light worked, so the light did not cause the accident. ${ }^{\text {ss }}$

the level of proof required for persuasion.) Thus, under traditional analysis, a defendant who inflicted allegedly fatal injuries and was both sued for wrongful death and tried for murder would face a plaintiff and a prosecutor each trying to establish the same causal fact: that the injuries were indeed lethal. The jury would need to be more certain of its conclusion to make the criminal conviction than to assess civil liability.

27. See infra note 46 and text accompanying notes $43-53$.

28. I. Hacking, supra note 25 , at 11-17.

29. See id.

30. See, e.g., Brilmayer \& Kornhauser, Review: Quantitative Methods and Legal Decisions, 46 U. ChI. L. Rev. 116, 136-45 (1978); Jaffee, Of Probativity and Probability: Statistics, Scientific Evidence, and the Calculus of Chance at Trial, 46 U. PITT. L. REv. 925 (1985); Kaye, The Laws of Probability and the Law of the Land, 47 U. CHI. L. Rev. 34 (1979); Wright, Causation in Tort Law, 73 CAL.If. L. REv. 1735, 1822 nn.363-65 (1985) (and sources cited therein).

31. Robinson, Multiple Causation in Tort Law: Reflections on the DES Cases, 68 VA. L. REv. 713, 766 n.173 (1982).

32. Id.

33. An example of "something else" is the "propensity" theory. See id. at 766 n.172.

34. In other words, the Note proceeds from the premise that "there are circumstances in which each interpretation provides a satisfactory account of the probability statement concerned," as well as "important theoretical and practical differences." Id. at 766 n.173.

35. A couple of qualifiers are necessary for this hypothetical. First, assume that causation is the only contested issue, laying aside other possible complications such as possible governmental immunity 
Evidence might be heard on such factors as the vehicle's speed, its braking ability, and the driver's reaction time.

Among the elements of the case which plaintiff has the burden of proving is causation-in-fact. In this example, the specific "fact" to be proven is that the car actually could have stopped in time. This fact is either true or false-its probability is really either 0 or 1 .

If the jury finds liability, it must find that the light truly caused the accident. ${ }^{36}$ But it need not be certain; it need only feel that the plaintiff's proof meets the preponderance of the evidence standard of persuasion. This is usually defined as a belief that causation is "more likely than not" true. ${ }^{37}$ In other words, the jury must be more than $50 \%$ confident in its conclusion. It might express this as: "We find a greater than $50 \%$ probability that the light caused the accident." The meaning is that the jury believes a knowable fact with more than $50 \%$ confidence. This type of probability I call "belief probability."ss

Consider the same case, but with no information available about the characteristics of the individual car. Instead, there is undisputed evidence that of 100 cars chosen at random, 53 would have been able to stop. The traditional outcome would be: "We believe that $53 \%$ of cars could have stopped, but we have no idea whether your car is in that group or not. Therefore, you have not met the burden of proof."39

Alternatively, the jury could find: "We accept the undisputed" fact that $53 \%$ of cars could have stopped. With no reason to find your car atypical, ${ }^{41}$ we infer that your car more likely than not would have stopped, since most cars would have." This finding incorporates a leap from an established fact about a population to a conclusion about a particular car. It can also be stated as: "It is more than $50 \%$ probable that the light

and contributory or comparative negligence. Second, assume that the jurisdiction would apply the doctrine of "but-for" causation to require a defendant's verdict if the city proved its argument.

The hypothetical falls into a category of causal conundrums that has been called overdetermined causation. See Wright, supra note 30, at 1787 . Because either cause is by itself sufficient to bring about the accident, neither can truly be considered a but-for cause. RESTATEMENT (SECOND) of ToRTs $\S 432(2)(1965)$ applies a substantial factor test to cases in this category, and would not permit the city to escape liability on causal grounds. Some courts apply similar logic to toxic torts. See infra note 77 .

36. Ball, supra note 20 , at 808 (trier of fact's determination is by convention "treated . . . as if the propositions found were true"). See infra note 52.

37. Prosser \& KeEton, supra note 26, § 41, at 269; MCCormick, supra note 22, 339.

38. Belief probability and fact probability are adequate labels in this context; for other verbal formulations, see I. HaCkING, supra note 25, at 12-15.

39. Some courts would still reach this result. See, e.g., Szczepaniak v. United States, No. 80-990MA (D. Mass. Mar. 2, 1985).

40. Complete acceptance is assumed merely to simplify the argument. It is not a necessary condition. See infra note 42.

41. This is an obviously critical assumption, possibly subject to contrary evidence in real cases. A "particularistic" showing of atypicality would invalidate the statistical inference, which is based on the assumption that the vehicle is a randomly selected member of the population studied. 
caused the accident." But the meaning of this finding is very different from the previous example, for here the plaintiff never tries to show that the light "really" caused the crash; the only "fact" being proven is that in most cases the light would have been the cause. This type of probability will be called "fact probability."42

\section{Implications for Toxic Tort Cases: "Collapsing"}

Because toxic tort plaintiffs and defendants rarely can introduce "particularistic" evidence which directly addresses the issue of causation in the individual case, ${ }^{43}$ causation can not properly be formulated as a yes-or-no fact.4 Rather, the parties can show an increased risk or enhanced probability of disease that results from defendant's conduct or from other, non-defendant causes. ${ }^{45}$ Thus, in toxic torts the causation inquiry is reduced to questions of the existence and magnitude of a fact probability. ${ }^{48}$

42. Both "fact" and "belief" probabilities might exist on a given issue in a real case. For example, a second study might claim that only $20 \%$ of cars could have stopped. The jury, in weighing the relative credibility of the studies, would apply its "belief probability" processes to a disputed "fact probability." Toxic tort cases require that the two types of probability be kept analytically distinct.

It may be easier to grasp the distinction by considering an element of the case other than causation. Suppose repeated surveys show that in a given situation, $60 \%$ of the population behaves in a way that is legally negligent. That probabilistic fact could not be expected to support a verdict against a particular defendant who was in the given situation. Yet, with conflicting evidence about the defendant's behavior, a jury's $60 \%$ belief in his negligence would of course support a plaintiff's verdict.

Rosenberg, supra note 18, at 870, argues that all evidence, even if styled "particularistic," involves inference from observed probability patterns. In some sense, this is irrefutable: all our rational conclusions are reached by applying a logical process of inference. When we see someone slip on ice and fall, we infer that the ice caused the fall partly because we know that people fall much more frequently when walking on ice than when walking on dry sidewalks. Yet our high belief probability about the cause of this particular pedestrian's fall depends crucially on individual observation as well. The fact that we see the ice overwhelms any inference we might have drawn from a table listing the relative frequencies of causes of falls. The power of particularistic proof to generate belief probabilities regardless of known fact probabilities requires us to treat particularistic evidence differently from group-based evidence, despite Rosenberg's argument. See supra notes 19, 41. See generally Wright, supra note 30 , at 1822-26 (more extreme argument that statistical reports entirely lack causal explanatory power of particularistic proof).

43. Even "easy" toxic tort causation cases are based on statistical correlations, but ones so strong and so exclusive that courts have little trouble believing them. See, e.g., Selikoff, Churg \& Hammond, Relationship Between Exposure to Asbestos and Mesothelioma, 272 NEw ENG. J. MED. 560 (1965) (extremely strong link between asbestos exposure and mesothelioma).

44. See Rosenberg, supra note 18 , at 855-58.

45. See supra text accompanying notes 11-19.

46. In the hypothetical, supra note 26 , this would mean that different facts (i.e., fact probabilities) would need to be proven to the civil and criminal juries deciding whether an alleged killer had caused the victim's death. Consider a case in which two defendants fire a total of 100 shots in the general direction of a victim, who is struck and killed by exactly one of the bullets. Assume that only one defendant can be held liable or found guilty, and the lethal bullet is irretrievable. Finally, assume the only evidence on which gun fired the fatal shot is testimony by someone with some knowledge of ballistics who counted the spent cartridges to determine how many came from each gun.

The traditional analysis, without collapsing the fact and belief issues, would be as follows:

Civil case: The fact to be proven is that the bullet in the victim's head came from the accused defendant's gun. The belief issues are: (1) How significant is the count of bullets to forming a conclusion about the individual fatal shot? (To form a "more likely than not" belief might require a higher 
Courts $^{47}$ and commentators ${ }^{48}$ have responded to this situation by collapsing the burden of proof and the standard of persuasion into a single test. The blurring of fact and belief probability conflates the two aspects which describe the plaintiff's task-the definition of the fact or element to be proven ("burden"), 4 and the amount of credence which must be given to that fact in order to support a finding ("standard"). ${ }^{\text {so }}$ Typically, the "collapsed" test is expressed in shorthand, i.e., "plaintiff must show that causation is more likely than not." traditional tort cases, but has never before worked a substantive change in the factual burden, because "more likely than not" always referred to be-

count than 51.) (2) How credible is the expert who counted the bullets?

Criminal case: The fact to be proven is the same as in the civil case. The belief issues are also the same, but to reach "beyond reasonable doubt" belief, the jury would likely require an even larger count of bullets from the accused defendant's gun.

In collapsed analysis, the issues would look different:

Civil case: The fact to be proven is that at least 51 of the bullets came from the accused defendant's gun. The belief issue is: How credible is the expert who counted the bullets?

Criminal case: The fact to be proven is that at least 95 (or any arbitrary high number equivalent to "beyond a reasonable doubt" standard) of the bullets came from the accused defendant's gun. The belief issue is: How credible is the expert who counted the bullets?

Under the collapsed regime, a question required by traditional analysis-in the above example, whether the casings count persuasively identifies the lethal bullet-is never asked. In the collapsed regime, the civil case is no stronger if the count from this defendant's gun is 65 than it would be if the count were 51 . In the traditional case, a higher count would strengthen jury belief that the accused defendant fired the fatal shot.

47. See, e.g., Jackson v. Johns-Manville Sales Corp., 727 F.2d 506, 516 n.17 (5th Cir. 1984) (plaintiff must establish greater than $50 \%$ chance cancer resulted from asbestos), reinstated in part and superseded in part on reh'g en banc, 750 F.2d 1314 (5th Cir.), questions certified, 757 F.2d 614 (5th Cir.), certification declined, 469 So. $2 d 99$ (Miss. 1985), on reh'g, 781 F.2d 394 (5th Cir.) (en banc) (affirming district court judgment), cert. denied, 106 S. Ct. 3339 (1986); In re "Agent Orange" Prod. Liab. Litig., 597 F. Supp. 740, 835-37 (E.D.N.Y. 1984) [hereinafter Agent Orange Fairness Opinion] (approving settlement of class action); O'Gara v. United States, 560 F. Supp. 786, 790 (E.D. Pa. 1983) (statistical evidence did not show Guillain-Barré Syndrome/swine flu link "more likely than not").

48. See Black \& Lilienfeld, supra note 3, at 766-67; Rosenberg, supra note 18, at 857; see also Kaye, The Limits of the Preponderance of the Evidence Standard: Justifiably Naked Statistical Evidence and Multiple Causation, 1982 AM. B. Found. RES. J. 487, 494 (discussing application of discounting rule developed for fact probability cases, see infra text accompanying notes 106-18, to cases involving only belief probabilities); Robinson, supra note 31 , at 732 \& $n .74$ (discussing preponderance standard in terms amenable to either fact or belief probability). Page, supra note 18, at 269, describes current doctrine in terms akin to "collapsing," yet his attempt to generate a sliding scale standard for belief probability does not clearly distinguish factual burdens from belief standards. Id. at 270-81.

49. The traditional burden was true-or-false causation; increasingly, in toxic torts, it is a fact probability higher than $50 \%$.

50. The traditional standard was "more likely than not"; increasingly, in toxic torts, it is impossible to determine. See infra notes 54-58 and accompanying text.

51. See, e.g., Agent Orange Fairness Opinion, 597 F. Supp. at 836 (must prove "probability of specific causation [is] more than 50\%"). 
lief probability. ${ }^{52}$ A plaintiff who set out to prove only a fact probability, as in Smith v. Rapid Transit, ${ }^{53}$ could not win.

In toxic tort cases, by contrast, some plaintiffs are being told that the fact that they must prove is not traditional true-or-false causation but the existence of a statistical probability of causation greater than $50 \%$. This shift of the $>50 \%$ standard from belief probability to the factual burden of proof has occurred quietly, almost unnoticed, yet it has had important effects.

\section{Consequences of "Collapsing"}

The haphazard and unrecognized infusion of "more likely than not" from the standard of persuasion into the substantive burden of proof leaves litigants, judges, and juries without clear guidance about the standards to apply as they weigh evidence and consider exactly what scientific "facts" must be proven and how clear the proof must be. Moreover, the false luster of numerical certitude in a simple quantitative rule (fact probability $>0.5$ ) is fallacious and distortional. This Part describes the adverse effects of "collapsing" on toxic tort adjudication.

\section{A. Loss of Meaningful Proof Standards}

With "more likely than not" folded into the factual burden, the preponderance test loses its value in determining the necessary level of belief. A fact-finder must decide whether it believes causation was in fact more likely than not without any exogenous standard indicating how strongly it must believe that.

Often, for example, toxic tort causation issues turn on which of several expert studies is accepted. ${ }^{\mathbf{5 4}}$ It is impossible to tell, without independent

52. See Nesson, The Evidence or the Event? On Judicial Proof and the Acceptability of Verdicts, 98 HARv. L. REV. 1357, 1360-63 (1985) (describing role of belief probabilities in reaching verdicts and distinguishing belief about evidentiary proof from that about factual events). "The relatively late emergence of probability as a mathematical concept ... suggests that the legal usage of 'probability' in standards of proof may be concerned more with evaluative concepts such as approvability and probity than with statistical probability." Id. at 1365 n.24; see also In re Winship, 397 U.S. 358, 370 (1970) (Harlan, J., concurring) (standard defines "degree of confidence [a jury] should have in the correctness of factual conclusions"); Kagehiro \& Stanton, supra note 25, at 166, 177 ("burden of proof" is to prove a fact to a subsequently defined level of persuasion; preponderance standard refers to evidence that "produces in your minds belief that what is sought to be proved is more likely true than not true") (quoting federal pattern jury instructions) (emphasis added).

53. 317 Mass. 469, 58 N.E.2d 754 (1945) (statistical likelihood alone insufficient to support finding that bus that injured Smith was defendant's); see also Bazemore v. Davis, 394 A.2d 1377, 1382 n.7 (D.C. 1978) (particularistic evidence superior to probability-based "presumptions"); King's Case, 352 Mass. 488, 225 N.E.2d 900 (1967) (mathematical likelihood insufficient to show cancer death was work-related).

54. Ordinary "battle of experts" cases are manageable because the preponderance standard provides a decision rule for weighing credibility and reaching a verdict based on belief probability; "collapsing" introduces chaos to this process. 
meaning for the preponderance standard, whether a court must be persuaded absolutely, more likely than not, or at some other level that the "winning" study is correct. O'Gara v. United States"s is a case in point. To reach a verdict, the court had to decide between two interpretations of a single epidemiological data set. The very choice it was making, between defendant's proffered fact probability and plaintiff"s, indicated that "more likely than not" had been collapsed into the factual burden. ${ }^{56}$ When it came time to apply the "preponderance of the evidence" standard to plaintiff's proffered proof, the court rejected the plaintiff's study because the assumptions underlying it were not "the only reasonable, or the most reasonable, assumptions ...."."67

Thus, in O'Gara, the substantive burden was to prove a fact probability greater than $50 \%$, and the standard of persuasion was to show that all other beliefs were unreasonable. In effect, the burden of proof was lowered but the standard of persuasion more than proportionately stiffened. Obviously, with the usual meaning of the preponderance test obscured, a large range of other standards of persuasion could have been applied. ${ }^{68}$

\section{B. Invisible Substantive Changes}

A number of difficult situations, for which rules have not yet been formulated by courts, are intractable if "fact probability" and "belief probability" remain undistinguished. Inevitably, cases involving conflicting or dramatically inconsistent scientific evidence will force courts to determine what they actually do when deciding toxic tort causation issues. Is the fact-finder reaching its own independent assessment of fact probability? Or is it weighing the conflicting evidence and choosing a fact

55. 560 F. Supp. 786 (E.D. Pa. 1983). The case involved the link between swine flu vaccine and Guillain-Barré Syndrome. The swine flu vaccine cases, which were heard in bench trials in United States district courts, produced a stream of published opinions discussing cause-in-fact. Such opinions are relatively rare because cause-in-fact is, after all, primarily a jury issue, rather than a matter of law. See infra note 64 and accompanying text.

56. See id. at 789 .

57. Id. at 790. Note that this begins to resemble the "beyond reasonable doubt" standard of criminal cases.

58. A related problem is the minimum sufficient quantum of proof. It is not clear, for example, whether a single epidemiological study, even if it is the only one offered, should be considered sufficient. The problem is worsened if the validity of the only extant study is criticized more or less strongly by opposing experts. Still more vexatious are situations in which several studies of approximately equal scientific quality reach opposing results. At least three approaches to resolving such conflicts suggest themselves: counting studies; automatically finding no preponderance because valid scientific opinion conflicts; or trying to reach a fine-tuned decision of which study is "best."

These difficuities exist in many kinds of cases, but are exacerbated by the unique characteristics of population-based data and its frequent position as the sole evidence on causation in toxic tort suits. The preponderance standard may not be the ideal remedy for these problems, but at least it is a standard. 
probability that is "more likely than not" correct? With both fact and belief probabilities in the same case, how is their interaction to be analyzed? ?s $^{\text {se }}$

There are at least two ways to apply the "more likely than not" rule to this interaction. Courts could apply the rule jointly to the fact and belief probabilities, reducing the alleged fact probability by a factor reflecting the fact-finder's doubt about its truth, or the rule could be applied sequentially, requiring only a "more likely than not" belief in a fact probability which itself may just barely exceed the 0.5 threshold. The first method would stiffen causation proof requirements, ${ }^{60}$ while the second would be a major relaxation in the causation rule. ${ }^{61}$ The choice between joint or sequential application of "more likely than not," therefore, decisively affects litigation outcomes. This decision should not be made sub silentio; rather, it should be recognized as a major substantive alteration. ${ }^{62}$

Nevertheless, courts have not explicitly discussed the fact-belief probability interaction, even though they necessarily confront it when using the "more likely than not" collapsed burden/standard. Typically, courts that "collapse" have evaded the issue by applying the $>50 \%$ rule only once--to the factual burden-in effect reducing the standard of persuasion to an all-or-nothing proposition. Where a traditional court would have sought a $>50 \%$ belief in a yes-or-no fact, a "collapsing" court seeks a yes-or-no belief in a $>50 \%$ fact probability. Since the finding of fact probability does not alter the language of "more likely than not," these courts act as if the statistical probability of causation is a true-or-false fact that may be known absolutely. ${ }^{68}$ This is not to suggest that fact-finders

59. Brilmayer \& Kornhauser, supra note 30 , at $140,145 \&$ n.104, imply that considering interactions between fact and belief probabilities-especially the "joint" analysis, infra note 60 -is invalid. See also Jaffee, supra note 30. But see Kaye, supra note 30 (criticizing Brilmayer \& Kornhauser view). However, none of these authors was thinking about toxic tort cases. The suggestion that it would be inappropriate to mix probability models simply does not work in a case where a jury, presented with evidence tending to prove a fact probability, must decide how strongly it believes the fact probability. Both types of probability must then be considered. See supra note $\mathbf{4 2 .}$

60. In other words, the fact probability, when appropriately reduced to reflect uncertainty of belief, still has to exceed 0.5 . Mathematically, the probabilities are multiplied, yielding the rule: fact probability $\mathrm{x}$ belief probability $>0.5$.

This approach makes causation still more difficult to prove because even very high fact probabilities that are believed to be "more likely than not" can still fail the test (for example, $0.9 \times 0.55<0.5$ ). Conversely, a highly credible study that features a fact probability just over 0.5 will also fail, though it would almost certainly produce a finding of causation under the present "more likely than not" mixed burden/standard. (Nothing compels fact-finders to treat these two studies symmetrically; the more credible study with the lower reported fact probability should be preferred.)

61. Mathematically, this is expressed as two separate criteria: fact probability $>0.5$ and belief probability $>0.5$. Thus, a $51 \%$ belief in a 0.51 fact probability allows recovery, even though the "real" belief in causation, considering both types of probability, would be just $0.51 \times 0.51=0.2601$. Hence, this rule is substantially less stringent.

62. See infra note 86 and accompanying text.

63. This process differs from a jury's treatment of causation as a yes-or-no proposition for factfinding in a traditional case. See supra text accompanying notes 20-26. The jury reaches its conclu- 
are so naive they fail to realize that scientific findings are subject to dispute; still, they more or less inevitably, in this regime, pick a value without explicitly addressing belief probabilities. For example, in swine flu cases courts generally adopted the epidemiological estimates of the Centers for Disease Control (GDC) as if they were determinative. ${ }^{64}$ Had some of these courts undertaken a two-step probabilistic analysis outcomes might have been different. One court, faced with seven estimates of background risk, and hence of the vaccine's probable role, ${ }^{65}$ acknowledged that "a finding of a single true base rate would be wholly arbitrary." court suggested that plaintiff's burden was to prove such a rate. ${ }^{67}$

\section{Fixation on Single Values}

Use of a simple quantitative rule as the fact probability burden promotes placing undue emphasis on the particular probability of causation as found in an epidemiological study. This number must exceed 50\%; if it falls even marginally lower, no fact-finder could rationally claim that the evidence establishes that causation is "more likely than not." This is true

sion with acknowledged uncertainty, although the conclusion is subsequently treated, for legal purposes, as if certain. In "collapsing," at the outset of legal analysis, a statement of fact with inherent uncertainty is treated as if that uncertainty did not exist. The legal system pretends that the study shows " $x$ is $44 \%$ " instead of recognizing that what the study really shows is " $x$ is more or less $44 \%$." Because the probability scale is continuous rather than discrete-it is expressed numerically rather than as yes-or-no-it is possible to act as if the values are precise even though such treatment is inappropriate. Most crucially, courts which behave in this way fail to apply belief probability processes to the statistical fact probability, thus compounding the crror.

Commentators, no less than judges, propagate the myth of certain, knowable probabilities. See Delgado, supra note 5, at 899 ("[w] burden of proof should shift); McElveen \& Eddy, supra note 3, at 64-65 (describing proposals for proportional recoveries for radiation injuries); Rosenberg, supra note 18, at 859 \& n.43 ("The court would derive the probability of causation from the available statistical evidence by dividing the excess risk by the total risk....").

64. The CDC studied Guillain-Barré Syndrome (GBS), a severe neurological disorder, and concluded that it was linked to the vaccine, but only when contracted within a relatively short period after vaccination. Most reported cases involved plaintiffs trying to recover for GBS which occurred after a longer delay. See, e.g., Beall v. United States, 567 F. Supp. 131, 134 (M.D. Pa. 1983) (no excess risk of GBS by time of onset), affd without opinion, 735 F.2d 1347 (3d Cir. 1984); In re Swine Flu Immunization Prods. Liab. Litig., 508 F. Supp. 897, 905 (D. Colo. 1981) ("Schonberger [CDC] study reveals that $70 \%$ of the increased incidence of GBS occurred within three weeks of vaccination."), affd sub nom. Lima v. United States, 708 F.2d 502 (10th Cir. 1983).

The swine flu cases are in some ways atypical toxic torts, because they involve a single, known exposure to a biological, rather than chemical, agent, and because the injuries, while non-traumatic and latent, appeared relatively soon after exposure. The short latency periods and firm knowledge of exposures, however, sharpen the cases' focus on causation.

65. Cook v. United States, 545 F. Supp. 306, 315-17 (N.D. Cal. 1982). The highest estimate was more than double the lowest.

66. Id. at 315 .

67. "[P]laintiffs' data are insufficient to prove causation, inasmuch as they fail to establish [an] attack rate [for vaccinees] in excess of twice the upper limit of the reasonable range." Id. at 316 . In other words, the court required the plaintiffs to demonstrate a relative risk of at least two, corresponding to a fact probability of at least $50 \%$. 
even if the court recognizes that statistical estimates are imprecise, ${ }^{68}$ bounded by confidence intervals of arbitrarily variable widths. ${ }^{69}$ It is obvious that the confidence interval for a given estimate could easily fall on either side of any numerical requirement ${ }^{70}$ yet courts are likely to fix on the reported mean value. ${ }^{71}$ This kind of rigidity is particularly inappropriate because, in fact, population-based probability estimates do not speak to probability of causation in any one case; the estimate of relative risk is a property of the studied population, not of an individual's case. ${ }^{72}$

68. Examples of futile recognition of statistical limits can be found in academic papers as well as court opinions. Discussing Sindell, two authors write: "A statistician would here want to know about standard errors, of course." Fraser \& Howarth, supra note 6, at 143 n.59. They do not instruct how a lawyer could take the standard errors into account.

69. Values generated by sampling studies are estimates of "true," or parametric, population values. Thus, even identically performed studies are likely to give differing numerical results. These results are conventionally reported as values plus or minus their standard errors, from which a "confidence interval" can be derived. The width of the confidence interval depends on the level of confidence sought. See generally R. Sokal \& F. Rohl.F, Biometry 52-53, 140-45 (2d ed. 1981).

70. E.g., Berkowitz, Kelsey, et al., Oral Contraceptive Use and Fibrocystic Breast Disease [FBD] Among Pre- and Postmenopausal Women, 120 AM. J. EPIDEMIology 87 (1984) (among postmenopausal women who used oral contraceptives for less than two years, relative risk 2.29 for FBD bounded by $95 \%$ confidence interval of 1.09 to 4.83 ); Hadjimichael, Meigs, Falcier, Thompson \& Flannery, Cancer Risk Among Women Exposed to Exogenous Estrogens During Pregnancy, 73 JNCI: J. NAT'L CANCER INST. 831 (1984) (observed relative risk for all cancers is 1.46 for persons who took DES; $95 \%$ confidence interval ranges from 1.07 -virtually no effect of exposure-to 2.00-the threshold of complete recovery under "more likely than not" fact probability rule).

71. See, e.g., McDonald v. United States, 555 F. Supp. 935, 956 n.32 (M.D. Pa. 1983) (quoting estimated probability of swine flu vaccine/GBS link by week; some single values and some ranges, but no mention of confidence intervals).

72. Technically, the probability derived from an epidemiological or other group-based study is a property only of the group. One can say that there is $x$ probability that any random case picked from the population will be a case of "true" causation. This is subtly different from saying, of any particular individual's disease, that its probability of "true" causation is $x$. Although unknowable, the propcrty of individual causation is, in fact, true-or-false: either the individual's disease is a background case, and would have occurred without exposure, or it is actually caused by exposure to a toxic material. It cannot be $55 \%$ one and $45 \%$ the other. (Cancer causation may well be a multi-step process not well suited to simplistic true-or-false analysis. See Cartwright, Cancer Epidemiology, in I CHEMIcal Carcinogens 18-19 (C. Searle 2d ed. 1984). Nevertheless, for any stage of cancer initiation or promotion, the distinction between population and individual properties holds.)

As Sokal and Rohlf explain in the context of confidence intervals:

We must guard against a common mistake in expressing the meaning of the confidence limits of a statistic. [These limits] imply that the probability of this interval covering the mean is 0.95 or, expressed in another way, that on the average 95 out of 100 confidence intervals similarly obtained would cover the mean. We cannot state that there is a probability of 0.95 that the true mean is contained within any particular observed confidence limits, although this may seem to be saying the same thing. The latter statement is incorrect because the true mean is a parameter; hence it is a fixed value and it is therefore either inside the interval or outside it. It cannot be inside a particular interval $95 \%$ of the time.

R. SOKal \& F. RoHLF, supra note 69, at 144.

The confusion warned against in the statistics text is apparent in Padgett v. United States, 553 F. Supp. 794 (W.D. Tex. 1982), a swine flu case:

[T] he relative risk to a vaccinee . . . is determined by dividing the attack rate among vaccinees

in a given population by the attack rate among non-vaccinees in that population. . .

From the relative risk, we can calculate the probability that a given case of GBS was caused by vaccination. . . [A] relative risk of 2 or greater would indicate that it was more likely than not that vaccination caused a case of GBS. 
Even courts aware of these limits of statistics find no way to apply them in the face of quantitative rules and numerical estimates. For example, in Allen $v$. United States, ${ }^{73}$ where plaintiffs alleged that their cancers had been caused by radiation from nuclear tests, the court criticized blind reliance on statistical estimates, ${ }^{74}$ and explicitly rejected the $>50 \%$ rule on causation." Allen also rejected the traditional "but for" definition of causation $^{76}$ in favor of a "substantial factor" test. ${ }^{77}$ Despite all this, only 10

Id. at $800-01$. The description of the population statistic is accurate; the leap to direct inferences about a single case is technically incorrect. This distinction has more than passing force: no matter what the relative risk, a plaintiff's case could easily and thoroughly be vitiated by a showing that the particular plaintiff had been exposed, at an appropriate time prior to the illness, to another known risk factor (e.g., for GBS, a respiratory infection immediately before onset). See generally Fraser \& Howarth, supra note 6, at 139 ("historical" proof differs from group-based "actuarial" proof).

73. 588 F. Supp. 247 (D. Utah 1984).

74. Id. at 416-18. The court noted, for example, that statistical significance implies a much greater level of confidence in the "reality" of a scientific finding than is normally required by courts. Statistical significance tests calculate the probability that an observed difference between sampled populations arose from random sampling error, instead of reflecting a "true" difference between the parametric values. See R. SokAl. \& F. RoHLF, supra note 69 , at 157-77. Scientific convention requires a less than $5 \%$ probability that sampling error could account for observed differences. A court which employs $50 \%$ standards of belief might thus never see an "insignificant" statistical finding, even though there might be a $90 \%$ chance that the finding reflects a real difference and not mere chance. Mechanical rules produce findings of no causation if a study shows either: (1) a statistically significant risk increase with a magnitude less than a doubling of background risk, or (2) a large increase in risk which is not statistically significant and hence can credibly be attributed to random error. See McElveen \& Eddy, supra note 3, at 67.

Dore, supra note 10 , argues that no epidemiological study should be admitted or used as a basis for expert testimony "[i]f the court is not satisfied that this risk ratio has been established within a 99\% confidence interval ...." Id. at 695 n.63. Of course any ratio will have some $99 \%$ confidence interval around it, see supra note 67 ; what Dore means to say is that no study should be accepted unless the ratio is significant at the $99 \%$ level, i.e., there is less than a $1 \%$ chance that it results from random error. There is no principled reason for preferring this significance level over $95 \%$ or, for that matter, 99.9\%. Insisting on a higher significance level does not alter the fact that the studies are populationbased, though it would be an effective device for excluding a large number of otherwise acceptable studies. However, as the Allen court noted, supra, there may be good reasons to lower the required significance threshold. On the other hand, the court's argument can be carried too far; accepting a study result that was significant only to the $50 \%$ level would be a gross error. See Fisher, Statisticians, Econometricians, and Adversary Proceedings, 81 J. Am. Statistical. A. 277, 280 (1986).

75. 588 F. Supp. at 418.

76. The definition of "but for" causation requires a showing that plaintiff would not have been injured if defendant had not acted. See Prosser \& KeEton, supra note 26, § 41.

77. Allen framed the test as follows: Does "a preponderance of the evidence [show] that the conduct of the defendant significantly increased or augmented the risk of somatic injury to a plaintiff and that the risk has taken effect in the form of a biologically and statistically consistent somatic injury"? 588 F. Supp. at 428 . This formulation gropes toward a distinction between the preponderance standard and the burden of proof: The undefined "preponderance" presumably means a "more likely than not" level of belief; the fact probability being proven is the vaguely defined "significant" risk increase.

Allen and Agent Orange Opt Out Opinion take vastly different approaches. Compare Agent Orange Opt Out Opinion, 611 F. Supp. at 1261 (adopting "but for" causation definition) with Allen, 588 F. Supp. at 415 (rejecting "but for" in favor of "substantial factor"). The Allen court used an analogy to Summers v. Tice, 33 Cal. 2d 80, 199 P.2d 1 (1948), the model indeterminate defendant case, see supra note 6 , and focused on defendant's conduct rather than the possibility of alternate, "innocent" causes. By relying on $\$ 432(2)$ of the Restatement, see supra note 35 , the court also implicitly rejected the traditional judicial view that any case of cancer has a single cause which the plaintiff must link to the defendant. $588 \mathrm{~F}$. Supp. at 411-12. Under Allen, exposure to a sufficiently potent carcinogen is deemed causative even though some of those exposed might not get sick. Proof of 
of 24 individual plaintiffs in Allen recovered. The results closely paralleled the expected outcomes under a more traditional analysis using a rigid numerical rule. ${ }^{78}$

\section{Narrowness in Evidentiary Rulings}

"Collapsing" also promotes a narrow focus on a particular type of evidence. Since the fact to be proven is now a statistically derived probability, it becomes tempting to exclude evidence that relates to causation but does not directly estimate the statistical value.

The Agent Orange case is a striking example: the court refused to consider any evidence except epidemiological studies of veterans. ${ }^{79}$ Animal studies were rejected because they were not done on humans. Epidemiological studies of industrial exposures were rejected because they were based on "inapposite data," namely a population which differed from veterans in amount of exposure and other characteristics. ${ }^{80}$ These studies were held not just inadmissible, ${ }^{81}$ but also insufficient as a basis for expert opinions. ${ }^{82}$ Other courts have made similarly narrow rulings. ${ }^{83}$

exposure plus a biologically consistent injury gives rise to an inference of causation. Id. at 415. Allen's view that cancer should be legally considered to have multiple causes contrasts sharply with the $O p t$ Out Opinion's insistence that all alternate causes be definitively ruled out. 611 F. Supp. at 1250-54. In light of the myriad toxic exposures we all experience, as well as the ubiquity of "background" or unexplained disease, the Allen approach seems to impose the more practical burden. See Cartwright, supra note 70. See generally J. MAUSNER \& A. BAHN, supra note 14, at 26-28 (epidemiological model of multiple causation).

78. For 10 of the 14 plaintiffs who did not recover, their key failure was inability to show an increased incidence of their cancers above background in the exposed population. $588 \mathrm{~F}$. Supp. at 429-40; $c f$. Agent Orange Opt Out Opinion, 611 F. Supp. at 1248 (similar problem for plaintiffs). In one case a $33.9 \%$ statistical causation estimate was held insufficient to show a "substantial factor," 588 F. Supp. at 440 n.199. Only two plaintiffs with epidemiological estimates below $50 \%$ prevailed. One showed a $47.3 \%$ probability plus persuasive particularistic evidence; the other contracted cancer of the thyroid, a very radiation-sensitive organ, after receiving a massive dose. Id. at 437-41.

The more traditional use of a rigid, quantitative rule is exemplified by swine flu cases such as O'Gara v. United States, 560 F. Supp. 786 (E.D. Pa. 1983) and Cook v. United States, 545 F. Supp. 306 (N.D. Cal. 1982).

79. Agent Orange Opt Out Opinion, 611 F. Supp. at 1234 (even studies showing a dioxin-disease link do not show "such a connection between plaintiffs and Agent Orange"). In this sense the court, even while rejecting the requirement of individual, particularized evidence, Agent Orange Fairness Opinion, 597 F. Supp. at 835-36, demanded evidence that was "particularistic" with respect to the class of plaintiffs or the population to which plaintiffs belonged. Of course, any number of boundaries may define that population, ranging from definitions so narrow that only one individual is included, to definitions so broad they are well-nigh universal. The court announced no standards for defining the relevant population.

80. Agent Orange Opt Out Opinion, 611 F. Supp. at 1241.

81. Id. (studies held irrelevant under FED. R. Evid. 401-03).

82. Id. at $1234,1241-45$. The court held that the studies would not be " 'reasonably relied' upon "by experts in the field," "as required by FED. R. EvID. 703. Id. at 1243. The court also seemed willing to substitute its view of the probative value of these studies for that professed by plaintiff's experts. Id. at 1238 ("Dr. Epstein concludes that 'a causal relationship exists' . . . . [based on studies which the court finds] collectively have the probative force of a scintilla of evidence.").

83. A case in point is Hupp v. United States, 563 F. Supp. 25 (S.D. Ohio 1982). Hupp sought to prove that a swine flu shot caused his multiple sclerosis (MS). He used circumstantial evidence, in- 


\section{A Better Approach to Gausation Burdens}

Rigid, simplistic rules offer no solution to the problems of proving toxic tort causation. Accordingly, the proposal which follows represents, not a set of standards, but rather a flexible approach which fosters case-by-case adaptation to the unique nature of toxic torts. Its central goal is to come to terms with causal indeterminacy in a way which is both legally and scientifically sound.

In addition to its primary purpose, the proposal is also designed to satisfy other criteria by which the tort system is often judged. Chief among these are the system's ability to provide appropriate deterrents to harmful conduct $^{84}$ and to compensate victims. ${ }^{85}$ It is also important to furnish a fair forum, with known and consistent rules, ${ }^{86}$ for vindication of individual rights. ${ }^{87}$ Finally, administrative costs should be minimized, or at least exorbitant expense discouraged. ${ }^{88}$

Trade-offs among these criteria plague any system, and the choice of acceptable trade-offs of course involves value judgments. Because this proposal is not designed to be a rigid set of rules, it can accomodate a diversity of these choices. Though any approach that addressed the current "collapsing" problem would be superior to extant jurisprudence, this Note's proposal avoids significant flaws of other schemes.

\section{A. Types of Causation Evidence}

Courts should broaden the range of evidence accepted on causation issues. Because no evidence in toxic torts can speak directly to individual causation, parties should be allowed to introduce many types of evi-

cluding: temporal proximity between vaccination and disease onset; known links between other vaccines and MS; known links between swine flu vaccine and neurological ailments other than MS; close physiological similarity between MS and GBS, an acknowledged result of the vaccine. The court held that only epidemiological evidence, which neither side produced, could have proven causation.

The forms of proof on which Hupp relied have received inconsistent treatment from courts. A similar but weaker argument that the vaccine had caused transverse myelitis was rejected in Szczepaniak v. United States, No. 80-990-MA (D. Mass. Mar. 2, 1985), which dubbed such evidence "medical precedent" and held it not probative. Another court, however, accepted such evidence as one type of several which, taken together, withstood a motion for summary judgment. Anderson v. Cryovac, Inc., No. 82-1672-S (D. Mass. July 25, 1984) (denying defendant's summary judgment motion in leukemia/toxic waste lawsuit).

84. Delgado, supra note 5, at 893-94.

85. Id. at 892-93; Hall \& Silbergeld, supra note 8 , at 444.

86. "[I]n a democratic society, ostensible law should reflect what is actually being done." V. Schwartz, Comparative Negligence $\$ 21.1$, at 338 (1974) (advocating de jure switch to comparative negligence despite evidence of its de facto operation).

87. For litigants, especially plaintiffs, vindication of rights may be as important as monetary compensation. See generally C. VAN STRUM, A BITTER FoG (1983) (discussing grievances of citizens exposed to herbicides); Galanter, Why the "Haves" Come Out Ahead: Speculations on the Limits of Legal Change, 9 LAw \& Soc'y REv. 95, 137 (1974) ("have-nots" often litigate for symbolic reasons).

88. See Rosenberg, supra note 18, at 887-904 (analyzing costs of administering various regimes). 
dence-animal and in vitro experiments, epidemiological data, analogous medical cases-with fact-finders free to decide which of the many inferences urged on them are reasonable. ${ }^{89}$ Courts must reject truly irrelevant evidence, of course. ${ }^{90}$ But in many toxic torts, all the evidence is indirect, making "irrelevance" extremely difficult to determine. The relevance requirement should not be used to exclude potentially useful evidence. ${ }^{91}$

The Agent Orange court's apparently contrary conclusion that epidemiological studies of the exposed population, narrowly defined, were the "only useful studies having any bearing on causation"92 sweeps too broadly. Inferences from animal and in vitro studies, as well as epidemiological studies of different populations, are controversial; nevertheless, they are widely supported by regulators ${ }^{93}$ and scientists. ${ }^{84}$ Perhaps they were insufficient, in the Agent Orange case, to raise a material fact question when confronted with substantial contrary epidemiology. The court's language, however, is open to the interpretation that such studies could never raise a material fact issue. This conclusion would be unjustified. Its adoption would create a serious risk of injustice to both plaintiffs and defendants, and would lead to inappropriate levels of deterrence and compensation. ${ }^{95}$

89. The validity of inferences of causation based on each of these types of evidence is debated. See infra note 94 . Yet balancing the credibility of such inferences is a uniquely appropriate role for factfinders.

90. FED. R. Evid. 402.

91. Relaxing relevance rulings does not mean that courts should stop monitoring the quality of evidence. Even if animal studies were deemed admissible in principle, a court would correctly exclude a manifestly unscientific one as not probative, even indirectly, of anything. See FED. R. EvID. 401 (evidence must tend to support probable existence or non-existence of "any fact . . . of consequence" to outcome).

92. Agent Orange Opt Out Opinion, 611 F. Supp. at 1231. Contra Wells v. Ortho Pharmaceutical Corp., 788 F.2d 741, 744-45 (11th Cir. 1986) (burden of proof did not necessarily require production of scientific studies showing statistically significant association between spermicides and congenital malformations in large population), cert. denied, 55 U.S.L.W. 3333 (U.S. Nov. 11, 1986).

93. See Ethyl Corp. v. EPA, 541 F.2d 1, 26-27 (D.C. Cir. 1976) (describing range of evidence acceptable for administrative risk assessments).

94. See Handbook of Carcinogen Testing (H. Milman \& E. Weisburger eds. 1985) [hereinafter HANDBOOK] (essays variously reporting utility of chemical structure analysis, epidemiology, in vitro tests, and animal bioassays for establishing carcinogenicity); Furst, A New Look at Arsenic Carcinogenesis, in ARSENIC 151, 152-53 (W. Lederer \& R. Fensterheim eds. 1983) (Interagency Regulatory Liaison Group accepts epidemiology, in vitro, and animal tests); Weisburger \& Williams, Bioassay of Carcinogens: In Vitro and In Vivo Tests, in 2 Chemical Carcinogens 1323, 1356-60 (C. Searle 2d ed. 1984) (appropriate methods of inference to humans exist); see also Clayson, Transspecies and Trans-tissue Extrapolation of Carcinogenicity Assays, in ORGAN AND SPECIES SPECIFICITY in Chemical Carcinogenesis 637 (R. Langenbach, S. Nesnow \& J. Rice eds. 1983) (hereinafter Species Specificity] (suggesting methodological improvements in extrapolation to humans); Crouch, Carcinogenic Risk Assessment-The Consequences of Believing Models, in SPECIES SPECIFICITY, supra, at 653 (same). But see Stevenson \& Deisler, An Industrial Perspective on Testing for Carcinogenicity, in HANDBOOK, supra, at 608 (emphasizing difficulty of making valid interspecies comparisons); cf. Adamson \& Sieber, Chemical Carcinogenesis Studies in Nonhuman Primates, in SPECIES SPECIFICITY, supra, at 129, 150-53 (stressing inapplicability of rodent studies but arguing for use of monkeys instead).

95. There is no a priori reason to believe that the types of evidence admitted or barsed would 


\section{B. The Standard of Persuasion: Belief Probability}

The "more likely than not" test should be applied only to the requisite strength of the fact-finder's belief, and not to the definition of the factual elements which the parties must prove. Refusing to collapse burden and standard into a single test is essential to restoring rationality to doctrine on causation in toxic torts. Juries should not be instructed that the preponderance standard means that plaintiffs must prove a fact probability greater than $50 \%$. Rather, they should be instructed that plaintiffs must establish certain facts (including causation, as defined in the next section) by evidence which convinces juries that the fact is more likely true than not.

\section{G. The Burden of Proof: Fact Probability}

The definition of the fact to be proven in meeting the causation burden should be a variant of the "substantial factor" test. ${ }^{98}$ An instruction including both the preponderance standard and the factual burden might read: "If you find by a preponderance of the evidence that defendant's conduct was a substantial potential cause, or substantially increased the risk, of plaintiff's disease . . . " The court might further define these terms: "'Preponderance of the evidence' means proof that convinces you that the substantial risk increase is more probably true than not. 'Substantial risk increase' means that, in light of all possible causes, the defendant's activity was a major contributor to the plaintiff's risk."

"Substantial" should certainly not be defined as a probability greater than $50 \%$ or any other arbitrary level. The subjective definition of "substantial factor" proposed here may be expressed as a connection between

favor either plaintiffs or defendants. See supra note 8 . Limitations on admissibility that led to erroneous decisions would not optimize deterrence, and would over- or undercompensate plaintiffs.

96. In operation, "substantial factor" causation as discussed here would resemble the "qualitative causation standard" of Trans-Science, supra note 5, at 443-44 \& n.69. Thus the suggestion that the "substantial factor test" would have juries engage in more trans-scientific speculation than the "qualitative standard," $i d$., is puzzling. The "qualitative standard" requires the jury to decide whether the substance was "hazardous," whether the exposure was "substantial," and whether a (probably hypothetical) dose-response relationship supported the inference that the injury was "consistent with the exposure." Id. at 444-45. There is simply no escaping this kind of inference in toxic tort cases.

Trans-Science calls on the jury to perform one complex and speculative task not required by this Note's proposal: balancing the total social benefits and costs of the injury-producing product. For the plaintiff to prevail, the balancing process must lead the jury to conclude that the defendant acted unreasonably. Id. at 446-48. In addition to changing causation rules, the "unreasonable conduct" requirement affects the availability of theories of liability in ways that could change case outcomes (i.e., by foreclosing strict liability theories).

Why the causation inquiry should hinge on a finding of unreasonable conduct is unclear. As TransScience points out, id. at 443 n.69, this Note acknowledges that a more subjective definition of the causation burden might tempt juries to commingle causation with culpability, and argues that such a tendency is not fatal to the proposal offered herein. This Note does not, however, propose any change in theories of liability, nor suggest that a finding of "fault" is essential to a finding of "cause." 
exposure and injury which is close enough to warrant liability. Though not a bright line standard, this test has proved workable both in other contexts $^{97}$ and for toxic torts. ${ }^{88}$ The main virtue of a subjective test is the shift in focus from a search for chimerical knowable "causes" to an evaluation of the defendant's conduct as it relates to the plaintiff's universe.99

"Close enough to warrant" blurs the burden in part because it contemplates a judgment which rests not solely on the factual existence of causation, but also on whether, given uncertainty about causation, imposing liability for certain conduct makes sense. ${ }^{100}$ Thus there is a possibility that the culpability of defendant's conduct will actually become part of the fact-finder's thinking on the causation issue. This combination of duty and causation is hardly foreign to tort cases, ${ }^{101}$ and may be entirely appropriate ${ }^{\mathbf{1 0 2}}$ when the duty involves protection of plaintiffs from a risk of unknown magnitude, and the approximate magnitude of the risk is central to the question of causation. ${ }^{103}$

The substantial factor test is more appropriate for evaluating toxic tort

97. The classic case is where two fires join and the court needs to decide whether each should be considered a substantial factor in causing damage which occurs after the fires combine. See, e.g., Anderson v. Minneàpolis, St. Paul \& Sault Ste. Marie Ry. Co., 146 Minn. 430, 179 N.W. 45 (1920). " 'IS]ubstantial factor" is a phrase sufficiently intelligible to furnish an adequate guide in instructions to the jury . . . ." Prosser \& KEETON, supra note $26, \S 41$, at 267.

98. The Allen court had little difficulty applying the standard to 24 disparate cases. Indeed, its application of "substantial factor" causation was only slightly more generous than "but for" rules. See supra notes 73-78 and accompanying text.

99. In a legal sense, the plaintiff's universe includes the conduct of all relevant parties as well as his or her individual characteristics. In an epidemiological sense, it includes a myriad of environmental and social factors. See J. MAUSNER \& A. BAHN, supra note 14, at 29-33 (ecological models of disease).

100. This approach might be criticized because it encourages the jury to decide "law" as well as "fact." However, even under traditional cause-in-fact burdens and standards of proof, the "fact" determination involves policy judgments. See Prosser \& KEETON, supra note 26, § 41, at 267-68; Lansing, supra note 5, at 8-9; Malone, Ruminations on Cause-in-Fact, 9 STAN. L. REV. 60, 61-64 (1956). Such mixed law and fact determinations are made by juries all the time, for example when deciding whether conduct is "negligent" or a product is "defective." But see Wright, supra note 30, at 1741-45 (insisting causal inquiry is purely factual).

101. Notions of "proximate cause" and foreseeability, for example, are bound up with concepts of duty and the extent of legal protections, as well as with factual issues. See Palsgraf v. Long Island R.R., 248 N.Y. 339, 162 N.E. 99 (1928) (discussing a single problem in terms of causation, duty, negligence, and foreseeability). In comparative negligence cases, it may be impossible to tell whether courts or juries are measuring relative culpability of conduct or contributions to causation. See $\mathrm{C}$. Heft \& C. Heft, Comparative Negligence Manual. $\$ \S 1.50,1.70$ (rev. ed. 1978) (blurring fault and causation); Robinson, supra note 31, at 748-49 nn.127-28 (apportionment of damages commonly mingles fault and causation). Sometimes the approved instructions may add to jury confusion, for example: "This case must be determined on the basis of comparative fault of the parties. . . . A party is at fault when he is negligent and his negligence caused ... the injury ...." KaNSAS Dist. Judges' Ass'N, PatTern InStructions for Kansas 20:01 (1966), quoted in C. Heft \& C. HeFr, supra, \& 7.54 (emphasis added).

102. See Allen, 588 F. Supp. at 411; see also Robinson, supra note 31, at 764 ("sufficient to warrant" commonly used to inject "practical judgments" into assessments of causal contribution).

103. The subjective "substantial factor" definition may seem less precise on its face than a rule that relies on a numerical threshold. However, because statistical estimates are themselves inexact, even the $>50 \%$ rule is only superficially a bright line. See supra text accompanying notes 68-78. 
causation than the traditional but-for test. ${ }^{104}$ It would replace the present doctrinal confusion caused by "collapsing" with an understandable rule. Moreover, because plaintiffs could recover in cases in which the defendant has clearly caused harm but traditional doctrine would bar recovery, the substantial factor test would assure more compensation, more deterrence, and more opportunities to vindicate rights than are currently available. To achieve this result without incurring economic inefficiencies, the substantial factor test should be linked to a method of discounting awards.

\section{Setting Appropriate Compensation Levels: Discounting Awards}

Any system of all-or-nothing awards is economically inefficient in toxic tort cases. ${ }^{105}$ David Rosenberg has suggested that the inefficiency may be eliminated by awarding a partial or "proportional" recovery, equal to total damages multiplied by the probability of causation. ${ }^{106}$ The proposal has merit, but it suffers from the same critical defect as the "more likely than not" rule: both embrace the myth of the magic number. Instead of the mystically sharp dividing line separating full liability from no liability (as with the $>50 \%$ rule), Rosenberg imagines a mystically precise probability that would determine the proportional recovery. His proposal would have plaintiffs pick their preferred probability, plead it, and prove ${ }^{\text {it, }}{ }^{107}$ while defendants could assert lower probabilities. ${ }^{108}$ The trouble is that it may be impossible rationally to choose any such value. Even a convincingly proven value would still be only an estimate; hence no scientific justification exists for setting the proportion equal to the reported value rather than at some other point in the reasonable range. ${ }^{109}$ Yet, under such a system plaintiffs and defendants would likely end up bidding

104. See supra note 77 and accompanying text.

105. Rosenberg, supra note 18 , at $862-66$. Assume a given defendant is responsible for $x$ amount of increased risk of some disease. All-or-nothing awards provide recovery to all plaintiffs if $x$ exceeds some threshold $y$; the aggregate payment is higher than it should be, and numerous plaintiffs collect even though their illnesses were not caused by defendant. Conversely, if $x$ is less than $y$ no plaintiff recovers, even though some clearly did suffer from illnesses caused by defendant. (The actual uncertainty of $x$, which Rosenberg fails to recognize, makes the inefficiency theoretically as well as practically incalculable, but does not affect its existence.)

106. Id. at 866-68.

107. Rosenberg, supra note 18 , at $896-900$.

108. Defendants would assert lower fact probabilities under any regime, trying to show that no recovery was warranted at all.

109. A scientist might argue that the reported value should be selected because it is the best available estimate. Indeed, if the sampling experiment is properly designed, the parametric value is more likely to be reported than any other given value; it is also very likely that the sample estimate will be close to the parametric value. But a second sampling experiment would nonetheless be very likely to yield an estimate different from the first. Although a number of repeated samplings could theoretically produce an extremely good estimate of the parametric value, in practice the fit is likely to be looser; and even though the scientific estimate may be the best one available, it is seldom, if ever, known with the precision which justifies legal application of a rule demanding exact numbers. 
for duplicative and wasteful studies, jockeying for possession of the study with the highest (or lowest) reported probability estimate. ${ }^{110}$

Rosenberg dismisses these concerns by asserting in a footnote that a "discernible consensus" is likely to exist on any particular substancedisease link at a given time. ${ }^{111}$ Unfortunately, such scientific harmony exists only in lawyers' wishful thinking. ${ }^{112}$ Epidemiology, like any science, is often marked by discord, ${ }^{113}$ especially at its frontiers. The protracted debate over the role of oral contraceptives in causing (or preventing) breast cancer ${ }^{114}$ is just one example. ${ }^{115}$ Even if epidemiologists agree on the exis-

110. These costs have moved some observers to call for comprehensive insurance schemes to replace the tort system. See Kinsley, Fate and Lawsuits: Litigation Doesn't Work. How About Socialism?, New Republic, June 14, 1980, at 3. While an administrative compensation scheme would make compensation more certain, it would also make it less complete, by denying awards for pain and suffering and probably not matching actual costs. See Brodeur, supra note 2, at 312-13. Moreover, causation might well be a pox on the agency's house. See supra note 2.

111. Rosenberg, supra note 18 , at 899 n.181.

112. The swine flu cases demonstrate that even a single data set may be interpreted differently by reasonable scientists. See supra notes 55-58, 64-67 and accompanying text.

113. See Horwitz \& Feinstein, Methodologic Standards and Contradictory Results in Case-Control Research, 66 AM. J. MED. 556, 558 (listing 17 epidemiological hypotheses on which studies conflict).

114. See Stadel, Rubin, Webster, Schlesselman \& Winga, Oral Contraceptives and Breast Cancer in Young Women, 1985(II) THE LANCET 970 (relative risk of breast cancer for pill users in all age groups very close to 1.0 [i.e., no increase in risk]-with fairly wide $95 \%$ confidence limits-contradicting two 1983 studies finding relative risks of three to four). This study sparked lively debate among epidemiologists who had studied the pill/breast cancer relation. See Breast Cancer and Oral Contraceptives, 1985(II) The LANCET 1180-81 (letter of Olsson, Ranstam \& Moller, and letter of Pike); Oral Contraceptives and Breast Cancer in Young Women, 1986(I) The LANCET 436 (letter of Stadel, Rubin, Wingo \& Schlesselman). The editors of The Lancet, reviewing studies which had shown beneficial, harmful, or no effect of oral contraceptive use on breast cancer risk, concluded: "Scientists, family planners, and general practitioners must be confused by the diversity of results now before them." Another Look at the Pill and Breast Cancer, 1985(II) THE LANCET 985, 985 (editorial). A recently published study sampled nearly 10,000 women and confirmed that the pill does not affect breast cancer rates. Oral-Contraceptive Use and the Risk of Breast Cancer: The Cancer and Steroid Hormone Study of the Centers for Disease Control and the National Institute of Child Health and Human Development, 315 NEw ENG. J. MED. 405, 406 (1986) (for study sample as a whole, relative risk $1.0,95 \%$ confidence interval $0.9-1.1$ ). And that, it appears, is that-at least for the time being. Shapiro, Oral Contraceptives-Time to Take Stock, 315 NEw ENG. J. MED. 450, 450 (1986) (urging further study but admitting "reasonable conclusion is that the oral contraceptives used in the United States do not increase the risk of breast cancer").

115. A cursory review of epidemiological literature reveals additional examples. The relative risk of respiratory cancer resulting from occupational exposure to arsenic has been estimated at anywhere from 3 to 60. N. Sax, Cancer Causing Chemicals 290-91 (1981). Studies of a single smelter in Tacoma, Washington, have found, in the most heavily exposed workers, approximately $8.3,2.5$, and 4.1 times as many respiratory cancer deaths as expected in a non-exposed population. Enterline \& Marsh, Mortality Among Workers Exposed to Arsenic and Other Substances in a Copper Smelter, in ARSENIC 226, 235 (W. Lederer \& R. Fensterheim eds. 1983); Lee-Feldstein, Arsenic and Respiratory Cancer in Man: Follow-up of an Occupational Study, in ARSENIC, supra, at 245, 248. Yet the validity of inferences from these studies is debated. See Furst, supra note 94 . Another current disagreement concerns linkage between soft tissue sarcomas and occupational (not veterans') exposure to phenoxy herbicides (e.g., Agent Orange). See Wiklund \& Holm, Soft-Tissue Sarcoma Risk in Swedish Agricultural and Forestry Workers, 76 JNCI: J. NAT'L CANCER INST. 229 (1986) (reported relative risk estimates range from 0.9 to 6.0 ).

The examples just described generally involved studies with differing methodologies or populations being sampled. These differences create a source of variation in result that is distinct from, and adds 
tence of a causal relation, they often differ widely in their estimates of its quantitative extent. ${ }^{116}$

On the other hand, Rosenberg's trenchant critique of all-or-nothing rules is too significant to be ignored in any proposal for toxic tort reform. This proposal attempts to find a middle ground by abandoning all-ornothing recovery but seeking to minimize precise numerical requirements. Juries ${ }^{117}$ should be permitted to discount their awards, but should do so without openly adopting a probability estimate. A smoker exposed to benzene and dying of lung cancer would recover less than an otherwise identical non-smoker. How much less would depend on the jury's overall evaluation of the case. ${ }^{118}$ Juries should not be limited to particular fact

to, the random variation that would be expected between two successive samples of the same population using the same methodology.

116. For example, aromatic amino compounds used in the dye and leather industries have been suspected of causing bladder cancer since at least 1895. Reported relative risks for exposed workers in several countries have ranged from 30 to 47 in earlier studies and 8.7 to 17 in later studies (after production methods were changed to reduce workers' exposure). W. HuEPER, Occupational AND Environmentai. Cancers of the Urinary System 119, 156 (1969). Cancer of the pancreas, for which cigarette smoking is "[b]y far the most suspect cause," is another good example. One study found a twofold increase in risk among smokers, while another found a relative risk of five to six. N.Y. Times, Mar. 25, 1986, at C1, col. 1.

Pancreatic cancer also illustrates the rapid swings of scientific opinion. Reports in the early 1980's linking the disease to coffee consumption had been fairly well discredited by 1986. See id.; Mack, Yu, Hanisch \& Henderson, Pancreas Cancer and Smoking, Beverage Consumption, and Past Medical History, 76 JNCI: J. NAT'L. CANCER INST. 49, 56-57 (1986).

117. Some may question whether juries are competent to evaluate the complex and technical evidence on causation in toxic tort cases. Compare In re United States Fin. Sec. Litig., 609 F.2d 411, 427 (9th Gir. 1979) (juries understand complex evidence) with In re Japanese Elec. Prods. Antitrust Litig., 631 F.2d 1069, 1086 (3d Cir. 1980) (jury confusion may deny due process of law).

Empirical evidence on jury competence is scarce. The Chicago Jury Project found that, in ordinary personal injury cases, judge and jury agreed on the liability question $79 \%$ of the time. Kalven, The Dignity of the Civil Jury, 50 VA. L. REv. 1055, 1065 (1964). Mock juries have generally been able to understand complex cases. Hastie, Implications for Law and Social Science, in INSIDE THE JURY 230 (R. Hastie, S. Penrod \& N. Pennington eds. 1983) (mock juries in murder case "remarkably competent" at fact-finding). But cf. A. Austin, Complex Litigation Confronts the Jury System: A CASE STUdY 99 (1984) (juries in two trials of complex antitrust case had "serious problems in comprehending vital information," but case study still did not support a priori rejection of juries in complex cases).

The easiest answer to concerns about juries' technical competence, however, is to substitute "factlinder" wherever "jury" appears in this Note. Should the "complexity exception" to jury trial of Japanese Electronics spread, toxic tort cases could be tried to the bench, or even to a specialized court which might be set up to hear such cases.

118. For either the smoker or non-smoker, the jury could conclude that the plaintiff had failed to prove benzene was a substantial factor in causing the cancer, and thus find no liability and zero recovery. This possibility makes it clear that both this Note's proposal and Rosenberg's approach call for discounting of damage awards depending on uncertainty as to causation, a liability issue. Mixtures of liability and damages issues are generally contrary to doctrine, yet it is likely that juries conduct such analyses all the time. In a mock jury study, juries facing ambiguous liability issues returned plaintiffs' verdicts averaging about $20 \%$ lower than juries hearing the same case with clearer evidence of liability, even though the damage evidence was the same. Kalven, Report on the Jury Project, in Conference on Aims and Methods of Legal Research (A. Conard ed. 1955), reprinted in C. JOINER, CIVIL. Justice AND THE JURY 201, 206 (1962). Such "compromise verdict[s]," "where the jury, in doubt as to [liability] . . brings in a verdict for the plaintiff but in a smaller amount that [sic] it would have if these questions had been free from doubt," McIntyre v. Clark, 314 
probabilities of causation espoused by a party, and pleadings should allege facts meeting the general substantial factor burden of proof, not any particular probability. Special verdicts stating the discount factor should not be permitted, lest lawyers use this insight into the details of jury thought processes as a lever to return to precise probability pleading.

This system of Gestalt award discounting has significant advantages over current practice and Rosenberg's proposal. It approximates the deterrence optimization of quantified proportional recovery, ${ }^{119}$ but does not impose unrealistic information demands, ${ }^{120}$ create false illusions of exactitude, nor encourage unduly narrow thinking on causation questions. Its key feature-intuitive discounting without proof of specific percentages-has been endorsed by at least one court. ${ }^{121}$ The proposal enhances

Pa. Super. 552, 557, 461 A.2d 295, 298 (1983), are believed to occur frequently. See, e.g., Kirby v. Larson, 400 Mich. 585, 655, 256 N.W.2d 400, 433-34 (1977) ("every trial judge knows" compromise verdicts are common) (quoting Karcesky v. Laria, 382 Pa. 227, 234, 114 A.2d 150, 154 (1955)). Some courts have accepted the inevitability, and even good sense, of liability-damages tradeoffs. E.g., Klein v. Eichen, 63 Misc. 2d 590, 310 N.Y.S.2d 611 (Sup. Ct. 1970) (alleged compromise verdict will not be overturned absent clear irrationality of damage award); Boyd v. Hertz Corp., 219 Pa. Super. 488, 498, 281 A.2d 679, 685 (1971) ("Compromise verdicts are both expected and allowed.").

As suggested, supra note 101, the concept of "causal negligence" makes it almost certain that juries in comparative negligence cases reduce damages to reflect doubts about the extent of causation as well as about negligence. See C. HeFT \& C. HeFT, supra note 101, \$1.70; V. SCHWARTZ, supra note 86, $\$ \S 4.1-4.3$ (arguing, in support of comparative negligence, that it should not affect cause-in-fact determinations, but conceding that blameworthiness and substantial factor determinations are combined).

119. Indeed, given the uncertainties which Rosenberg ignores, see supra notes 107-16 and accompanying text, it is not at all clear that his proposal would achieve the economic optimum which is its goal.

120. Other proposals would also require unobtainable knowledge. Page, supra note 18, would require juries to adopt a belief in a specific probability of causation and evaluate that probability against a sliding-scale standard, which would vary depending on estimates of the social costs and benefits of the substance involved. Even if such costs and benefits could ever be known, they would surely be undiscoverable by the process of private litigation. $C f$. Rizzo \& Arnold, Causal Apportionment in the Law of Torts: An Economic Theory, 80 Colum. L. REv. 1399, 1408-09 (1980) (suggests jury calculation of "probabilistic marginal product"). Trans-Science, supra note 5 , also requires a cost-benefit calculation, but demands only a finding of whether costs or benefits were greater, rather than a quantitative solution.

121. Martin v. Johns-Manville Corp., 349 Pa. Super. 46, 502 A.2d 1264 (1985), appeal granted sub nom. Martin v. Owens Corning Fiberglas Corp., 510 A.2d 1389 (Pa. 1986). The precise issue in Martin was the appropriateness and practicality of jury estimation of causal contributions without proffered percentages to guide them. Plaintiff was an asbestos worker and cigarette smoker who became disabled as a result of emphysema and asbestosis. All experts testified that they could not assign fractions of causation to either smoking or asbestos. The trial court instructed the jury to award full damages if they absolved the cigarettes as a cause, and no damages if they absolved the asbestos.

If, however, you find that his condition is due both to his cigarette smoking and to his exposure to asbestos, then you first determine what the total amount of damages are, and then the next thing you do is determine what percent of his condition is due to cigarette smoking, and then you will reduce the total amount by the percentage that you find is due to cigarette smoking.

Id. at $50,502 \mathrm{~A} .2 \mathrm{~d}$ at 1266 (quoting trial transcript). The jury awarded plaintiff about $40 \%$ of total damages. $I d$.

On appeal, plaintiff did not argue that apportionment was in principle inappropriate or that the award was inadequate, but only that "an instruction on apportionment of damages is only warranted if there is evidence as to the percentage of the plaintiff's disability attributable to cigarette smoking and the percentage attributable to asbestosis . . . Id I at 51, 502 A.2d at 1267 . A unanimous sevenjudge court held that "the evidence that was produced was sufficient to enable the jury to reach a 
fairness, because plaintiffs are not prevented entirely from recovering by the inherent causal indeterminacy of toxic torts. ${ }^{122}$ It is also more just to defendants than Rosenberg's proposal because, unlike "pure" proportional recovery, ${ }^{123}$ the "substantial factor" test requires a minimum level of causal connection before allowing recovery. ${ }^{124}$

The present proposal is admittedly imperfect. Jury bias and caprice may be more problematic than in systems which quantify proportional recoveries. ${ }^{125}$ Even imprecise award discounting may tempt attorneys to try to prove specific fact probabilities; however, the vagueness of the jury findings would reduce these incentives. On balance, the proposal fixes less on specific values than the $>50 \%$ rule or a quantitative proportionality rule, and gives juries necessary, but reasonable, leeway to weigh multiple factors in reaching just results in complicated toxic tort cases.

\section{Conclusion}

Toxic tort causation has posed a challenge to the civil justice system, and the response to date has been inconsistent, inarticulate, and confused. The proposal outlined in this Note is a reasonable accommodation to the inherent need to rely on statistical evidence in toxic tort cases. Above all, courts must recognize the distinction between fact and belief probabilities and the danger of mingling them in a "collapsed" burden of proof/standard of persuasion. This recognition would make the rules of toxic tort litigation more rational and more explicit, even if none of the specific

rcasonable approximation of the harm due to each cause." Id. The jury appears to have done just that, eschewing the simple expedient of "splitting the difference" by awarding $50 \%$ of damages.

Martin is significant in one other respect. It applies the doctrine of apportionment, which usually is used against indeterminate defendants, to a non-defendant cause (cigarettes). It thus implicitly adopts the position that there is no analytical distinction between indeterminate plaintiffs and indeterminate defendants in at least some cases. See supra note 6.

122. Ideally, plaintiffs whose diseases were truly caused by toxic exposure would collect full damages, while plaintiffs with background cases would not collect. Because these determinations cannot be made, partial recovery for all is the best result. See Delgado, supra note 5, at 904.

123. Rosenberg's careful economic analysis implies that proportional recovery should be available no matter how small the (non-zero) fact probability, in order to avoid the inefficiency associated with any threshold. Rosenberg, supra note 18 , at $883,886-87$. Defendants would thus be liable for small or cven trivial risk increases that they caused.

124. The "substantial factor" threshold advocated here preserves a fairness-based reasonable minimum before imposing liability, on the principle that defendants should not pay judgments and defense costs for de minimis risks. This threshold also reduces the potential plaintiff's incentive to sue for all diseases which might conceivably be linked to toxic exposure. By contrast, the pure proportionality rule, though theoretically efficient, encourages victims of illness to engage in a fascinating, but extraordinarily costly, attempt to identify all risk factors to which they were exposed, quantify the relative risk from each, and seek a proportional recovery from all.

125. Advocating clear disclosure of operative legal rules while insulating jury thought processes from inspection may appear self-contradictory. However, this is a commonplace in American justice-judges struggle to sharpen definitions of case elements while juries apply those definitions in secret. The usual checks on fact-finders-written opinions in bench trials, the possibility of judgment n.o.v. in jury trials, and appellate review-would remain available under this Note's proposal. 
changes advocated herein were adopted. Clarifying the rules, William $\mathrm{O}$. Douglas observed in another context, is its own reward: "[T] The issue would be clearly stated, the misplaced emphasis would disappear, the social and economic factors involved in the decisions would receive careful consideration, and the articulation would be more definite and clear cut."

126. Douglas, Vicarious Liability and Administration of Risk I, 38 YALE L.J. 584, 604 (1929). 